Litteratur

. Aase S. Obduksjon - fremdeles gullstandard? Tidsskr Nor Legeforen 2013; 133 : 730.

2. Alfsen GC, Lyckander LG. Har kvalitetskontroll av dødsmeldinger i sykehus betydning for dødsårsaksstatistikken? Tidsskr Nor Legeforen 2013: 133: 750 - 4.

3. Alfsen GC. Medisinsk obduksjon ved dødsfall utenfor sykehus. Tidsskr Nor Legeforen 2013; 133: 756-9.

4. Sundby P. Alcoholism and mortality. Oslo: Universitetsforlaget, 1967.

Dette er en redigert versjon av et innlegg publisert som rask respons på nett 25.4. 2013. http://tidsskriftet.no/article/2991563/

\section{Nevrografi er som regel nødvendig}

Russwurm \& Finsen kommenterer i Tidsskriftet nr. 6/2013 (1) vår artikkel om nevrografi ved karpaltunnelsyndrom (2), og vi takker for responsen. Vi er fortsatt enige med den amerikanske ortopediforeningen, som anbefaler nevrografi før operasjon (3), fordi pasienten er tjent med at diagnosen er så sikker som mulig før man tar stilling til om man skal gjøre et operativt inngrep. Det er kombinasjonen av typiske kliniske tegn og typisk nevrografi som gir optimal informasjon om diagnosen karpaltunnelsyndrom (4).

Klinisk og nevrografisk undersøkelse gir gjensidig tilleggsinformasjon. Dersom man velger «typiske kliniske tegn» som gullstandard, vil ca. $15 \%$ ha normal nevrografi (4). Av 2137 pasienter henvist til vår seksjon med mistenkt karpaltunnelsyndrom i perioden januar 2008-oktober 2011 hadde 835 (39\%) normal nevrografi.

Skal pasienter med normal nevrografi også opereres? Noen får dessverre komplikasjoner eller skader i forbindelse med operasjonen. Russwurm \& Finsen rapporterte «23 tilfeller av overskjæringer av nerve» meldt til Norsk pasientskadeerstatning i perioden 2005-10 (1). Dersom både standard og utvidet nevrografi er helt normal, vil legen ofte fortsette diagnostikken eller tilby konservativ behandling. Noen velger allikevel operasjon, og i de fleste tilfeller er resultatet godt.

Det postoperative resultatet stemmer ikke alltid med den reelle diagnosen. Både placeboeffekt og spontan symptomremisjon hos pasienter med andre sykdommer kan bidra til symptomlindring. Pasienter med en uttalt aksonal trykknevropati i karpaltunnelen, kan oppleve svært langsom symptomlindring, også etter optimal kirurgisk frilegging.

Hvorfor er det fortsatt tilsynelatende uenighet om betydningen av nevrografi? Én av grunnene er dårlig kvalitet på mange vitenskapelige studier (2). I en studie som Russwurm \& Finsen fremhever (1), sammenlikner man tilsynelatende effekten av nevrografi og det postoperative resultatet (5). Ved å lese artikkelen fremgår det imidlertid at nevrografiresultatet verken ble brukt i diagnostikken eller i dataanalysen.

Nevrografi har en spesifisitet som er høyere enn $95 \%$ og gir informasjon om patofysiologiske endringer i medianusnerven (4). Nevrografi bør derfor som hovedregel benyttes i diagnostikk av karpaltunnelsyndrom. Vi synes også at det er fornuftig å satse på opplæring i klinisk diagnostikk og operativ teknikk (1). Et godt samarbeid mellom behandlende kirurg og klinisk nevrofysiolog bør også etableres.

\section{Trond Sand}

trond.sand@ntnu.no

Kari Todnem

Trond Sand (f. 1952) er spesialist i klinisk nevrofysiologi og nevrologi. Han er seksjonsoverlege ved Avdeling for nevrologi og klinisk nevrofysiologi ved St. Olavs hospital og professor i klinisk nevrofysiologi ved Institutt for nevromedisin, Norges teknisk-naturvitenskapelige universitet.

Ingen oppgitte interessekonflikter.

Kari Todnem (f. 1944) er dr.med. og spesialist i klinisk nevrofysiologi og nevrologi. Hun er overlege ved Avdeling for nevrologi og klinisk nevrofysiologi ved St. Olavs hospital.

Ingen oppgitte interessekonflikter.
Litteratur

1. Russwurm H, Finsen V. Nevrografi ikke alltid nødvendig. Tidsskr Nor Legeforen 2013; 133: 611 .

2. Todnem K, Sand T. Nevrografi ved karpaltunnelsyndrom. Tidsskr Nor Legeforen 2013: 133: 170-3

3. Keith MW, Masear V, Chung KC et al. American Academy of Orthopaedic Surgeons Clinical Practice Guideline on diagnosis of carpal tunnel syndrome. J Bone Joint Surg Am 2009; 91: 2478-9.

4. Jablecki CK, Andary MT. Floeter MK et al. Practice parameter: Electrodiagnostic studies in carpal tunnel syndrome. Report of the American Association of Electrodiagnostic Medicine, American Academy of Neurology, and the American Academy of Physical Medicine and Rehabilitation. Neurology 2002; 58: 1589-92.

5. Zyluk A, Szlosser Z. The results of carpal tunnel release for carpal tunnel syndrome diagnosed on clinical grounds, with or without electrophysiological investigations: a randomized study. J Hand Surg Eur Vol 2013; 38: 44-9.

Dette er en redigert versjon av et innlegg publisert som rask respons på nett 10.5. 2013. http://tidsskriftet.no/article/2961527/

\section{Legeetikk i forsikringsmedisin}

Medisinsk direktør Jan Harald Dobloug i Gjensidige Forsikring kritiserer i Tidsskriftet nr. 3/2013 Rådet for legeetikk for ikke å ha gitt selskapet medhold i tre av i alt 14 klager på leger for det han mener er ufullstendige eller misvisende legeerklæringer (1). Han mener dette er alvorlig fordi rådets vedtak ikke kan overprøves og blir retningsgivende.

Når en lege skriver en legeerklæring, opptrer hun som sakkyndig, og rådet er selvfølgelig enig med Dobloug i at leger har et ansvar for å gi korrekte og nødvendig utdypende opplysninger slik det fremgår av Etiske regler for leger Kapittel IV (2). Rådet har presisert legens ansvar i sine årsmeldinger (2) og i Tidsskriftet (3).

Det at forsikringsselskapet har fătt medhold i 11 av de 14 klagene, viser at rådet oftest har vurdert kritikken mot legene som berettiget. Av kasuistikkene som Dobloug presenterer, er bare Sak 3 gjenkjennelig. Der ble en legespesialist innklaget av forsikringsselskapet for å ha gitt en diagnose på sviktende grunnlag. Diagnosen og begrunnelsen for denne, fremgikk av en epikrise fra legespesialisten til en annen helseinstans, ikke til forsikringsselskapet. Saken ble ikke tatt opp til klagebehandling fordi rådet ikke har mandat til å ta stilling til medisinskfaglige forhold, jf. Reglement for Rådet for legeetikk §2, 2. ledd (2). De andre sakene er behandlet av rådet etter kontradiksjonsprinsippet, det vil si at både forsikringsselskapet og innklagede lege har hatt anledning til å gi sine versjoner og dokumentere sine begrunnelser. Sakene kan være langt mer omfattende og kompliserte enn kasuistikkene gir inntrykk av, og rådet har gjort sine vedtak ut fra sin vurdering om erklæringene oppfylte kravene med tanke på Etiske regler Kapittel IV ut fra den kunnskap legene hadde om pasienten på det tidspunktet erklæringen ble skrevet. Dobloug er bekymret for at rådet med sine vedtak har gitt legene for stort handlingsrom. Slike saker er imidlertid aldri like, og hver enkelt må vurderes opp mot Kapittel IV ut fra det som blir dokumentert av partene. Enkeltsaker vil derfor ikke kunne være retningsgivende for andre saker.

Legeforeningens medlemmer har gitt Rådet for legeetikk mandat til å vurdere saker opp mot Etiske regler for leger (2). I klagesaker som gjelder legeerklæringer, er det rådets oppgave å vurdere om legen har gitt de opplysningene som ut fra hennes kunnskap, er relevante og dekkende for saken, og at legeerklæring fyller formkravene som er nedfelt i Etiske regler for leger Kapittel IV (2). Hvorvidt forsikringsselskapets lege godtar innholdet i erklæringen som var utgangspunktet for klagen, er en medisinskfaglig vurdering som er rådet uvedkommende.

Trond Markestad

trond.markestad@helse-bergen.no

Trond Markestad (f. 1945) er forskningskoordinator ved Haukeland universitetssykehus. Han er leder for Rådet for legeetikk.

Ingen oppgitte interessekonflikter. 
Litteratur

1. Dobloug JH. Hvem vokter vokterne - legeetikk i forsikringsmedisinen. Tidsskr Nor Legeforen 2013; 133: 320-1.

2. Den norske legeforening. Etikk. http://legeforeningen.no/Emner/Andre-emner/ Etikk/ (21.5.2013).

3. Markestad T. Hva er en legeerklæring? Tidsskr Nor Legeforen 2010; 130: 296.

Publisert som rask respons på nett 14.5. 2013. http://tidsskriftet.no/article/ 2968488

\section{Rollebevissthet kontra «hvem vokter vokterne»}

I Tidsskriftet nr. 3/2013 er det en redaksjonell omtale av anonymisering av pasienthistorier og problemstillingen «hvem vokter vokterne» (1). Utgangspunktet er et innlegg fra en forsikringslege som ikke fikk medhold av Statens helsetilsyn i klage på allmennleges erklæring i forsikringssak. Han hevder at vår avgjørelse er «høyst diskutabel» (2). Vi finner derfor grunn til å legge frem anonymisert versjon av vårt vedtak:

I denne saken foreligger det en uenighet med hensyn til tolkningen av gjeldende erklcering, herunder hvilken vekt det skal tillegges at lege NN sin diagnostiske tankegang fremkommer i erkloringen/legejournalen ved at diagnosen XX er vurdert og usannsynliggjort.

Etter Statens helsetilsyns vurdering viser journalnotatene at lege $N N$ har tatt med XX som en differensialdiagnose, men altså redusert sannsynligheten for at denne diagnosen forelå. I begge journalnotatene påpekes det at symptomene YY ikke var observert. Familicer anamnese på XX ble dessuten avkreftet. I det siste notatet omtales en form for $Q Q$. Dette støtter opp om en sannsynlighetsovervekt for at «symptomene» kunne skyldes det organsystem som vanligvis gir årsak til «tilbakevendende plager» hos barn. Det vil si at lege NN etter vår oppfatning i tilstrekkelig grad reduserte sannsynligheten for at han burde mistenke XX. Legeerkloeringen ble skrevet da diagnosen XX var kjent. Vi oppfatter det som korrekt, og ikke $i$ strid med journalopplysningene, at legen $i$ ettertid anslår at diagnosen XX debuterte med de beskrevne symptomene et par år tidligere.

Av dette går det frem at vi har handlet i samsvar med vår rolle som tilsynsmyndighet. Journalføring og erklæringen innfrir åpenbart kravene $i$ helsepersonelloven om relevante og nødvendige opplysninger - som skal gjengis korrekt og objektivt. At dette skapte et etisk problem for legen i forsikringsselskapet, er en annen sak. Forsikringsselskapet løste den etiske siden av saken med å avslå utbetaling og si opp avtalen. Mottaker av legeerklæringen hadde altså selv virkemidlet - og benyttet det. Saken handler ikke om «hvem vokter vokterne», men rolleforståelse og -/bevissthet.

Det må ikke bli slik at behandlende leger avstår fra å nedtegne sin diagnostiske tankegang i frykt for at forsikringsleger klager til tilsynsmyndigheten eller fratar pasienter forsikringsrettigheter.

Svein Z. Bratland

szb@helsetilsynet.no

Anne Myhr

Svein Z. Bratland (f. 1943) er seniorrådgiver i Statens helsetilsyn.

Ingen oppgitte interessekonflikter.

Anne Myhr er fagsjef i Statens helsetilsyn.

Ingen oppgitte interessekonflikter.

Litteratur

1. Hem E. Hvorfor har dere skrevet om meg uten å spørre? Tidsskr Nor Legeforen 2013; 133: 261

2. Dobloug JH. Hvem vokter vokterne - legeetikk i forsikringsmedisinen. Tidsskr Nor Legeforen 2013; 133: 320-1.

\section{J. H. Dobloug svarer:}

Rådet for legeetikk ved leder Trond Markestad skriver i sin kommentar til artikkelen Hvem vokter vokterne - legeetikk i forsikringsmedisinen (1) at bare Sak 3 var gjenkjennelig for rådet. Tidsskriftets strenge praksis med hensyn til personvern må ta en del av ansvaret. Men at rådet ikke klarte å gjenfinne sak 1 og 2 var jo synd.

Slike saker er aldri like, og vurderingen av dem vil i større eller mindre grad bli basert på skjønn, slik rådets leder skriver. Men hvis rådets avgjørelser i enkeltsaker ikke kan være retningsgivende i andre saker, blir det lite behov for rådets veiledning i praktisk etikk.

I artikkelen ble det understreket at forsikringsselskapene er avhengige av korrekte og relevante medisinske opplysninger, $i$ henhold til Legeforeningens etiske regler. Leder Markestad skriver at det er uvedkommende for rådet hvorvidt forsikringsselskapets lege godtar innholdet i erklæringen eller ikke. Hensikten med artikkelen var ikke spørsmålet om å godkjenne innholdet i erklæringer eller ikke. Artikkelen var ment å illustrere tvilsomme erklæringer og hvordan «vokterne» har beskyttet dem.

I kommentarene fra Statens helsetilsyn ved Svein Z. Bratland \& Anne Myhr mer enn antydes det at forsikringsselskapets krav til redelighet i erklæringer kan føre til at legene avstår fra å «nedtegne sin diagnostiske tankegang». Er det grunn til å frykte det? Den angjeldende sak som ble innmeldt til Helsetilsynet, ble velvilligst vurdert én gang til, men ikke overraskende kom tilsynet til samme konklusjon det hadde kommet med tidligere.

I sin kommentar gir tilsynet en tredjegangs vurdering av saken, men også nå frikjenner de den aktuelle legen.

Kommentarene fra Rådet for legeetikk og fra Statens helsetilsyn illustrerer at uttalelser fra autoritative organer, som ikke er overprøvbare, er forutsigbare og vanskelige å korrigere.

Q.E.D.

\section{Jan H. Dobloug}

jan.dobloug@gjensidige.no

Jan H. Dobloug (f. 1950) er medisinsk direktør i Gjensidige Forsikring. Ingen oppgitte interessekonflikter.

\section{Litteratur}

1. Dobloug JH. Hvem vokter vokterne - legeetikk i forsikringsmedisinen. Tidsskr Nor Legeforen 2013; 133: 320-1.

\section{RETTELSE}

Doktoravhandlinger, Universitetet i Bergen

Gunn Marit Seberg

Tidsskr Nor Legeforen 2013; 133: 996

Riktig tittel på doktoravhandlingen til Bjørn Steinar Olden Nedrebø skal være:

Colorectal cancer in Norway. National treatment guidelines and outcomes.

Vi beklager feilen, den er rettet i nettutgaven. 